\title{
Vol. 38 No. 3 September 2016
}

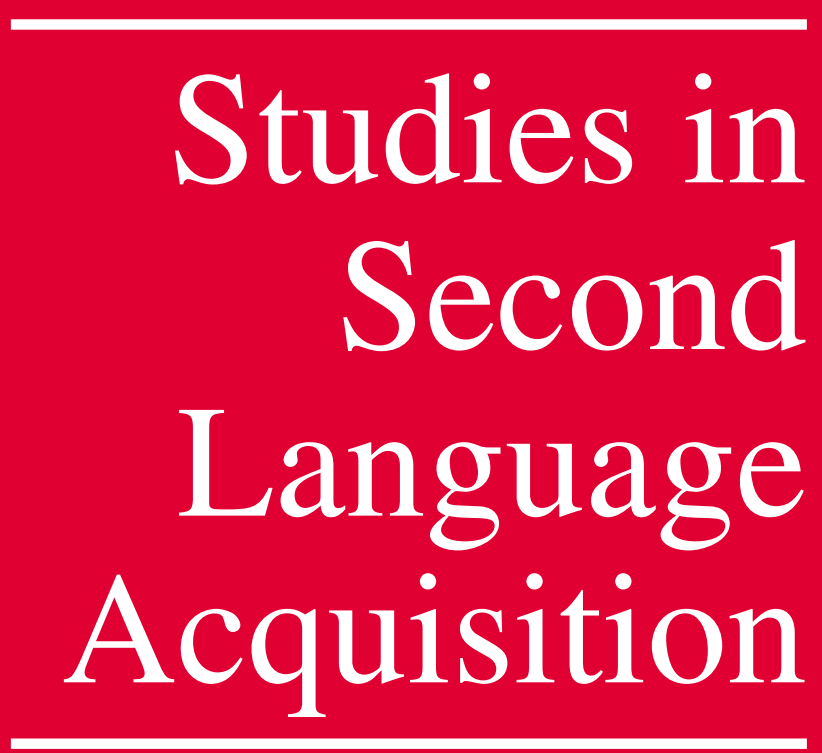

CAMbridge

UNIVERSITY PRESS 


\title{
STUDIES IN SECOND LANGUAGE ACQUISITION
}

\author{
Founding Editor: Albert Valdman (Indiana University) \\ Editors: Susan M. Gass and Bill VanPatten (Michigan State University) \\ Associate Editors: Kimberly L. Geeslin (Indiana University), Gregory Keating \\ (San Diego State University), Luke Plonsky (Georgetown University), \\ Andrea Révész (UCL Institute of Education)
}

\section{Editorial Board}

Niclas Abrahamsson (Stockholm University, Sweden), Gerald P. Berent (National Technical Institute for the Deaf at Rochester Institute of Technology), Jasone Cenoz (University of the Basque Country, Spain), Laura Dominguez (Southampton University, UK), Fred Eckman (University of Wisconsin, Milwaukee), Rod Ellis (University of Auckland, New Zealand), Alison Gabriele (University of Kansas), Aline Godroid (Michigan State University), Tania Ionin (University of Illinois at Urbana-Champaign), Shinichi Izumi (Sophia University, Japan), Carrie Jackson (Pennsylvania State University), Vera Kempe (University of Abertay, Scotland), Usha Lakshmanan (Southern Illinois University), Michael H. Long (University of Maryland, College Park), Roy Lyster (McGill University, Canada), Alison Mackey (Georgetown University), Kara Morgan-Short (University of Illinois at Chicago), William O'Grady (University of Hawaii), Graeme Porte (University of Granada, Spain), Peter Robinson (Aoyama Gakuin University, Japan), Yasuhiro Shirai (University of Pittsburgh), Patti Spinner (Michigan State University), Darren Tanner (University of Illinois at Urbana-Champaign), Margaret Thomas (Boston College), Richard F. Young (University of Wisconsin, Madison), Eve Zyzik (University of California at Santa Cruz)

\section{EDITORIAL POLICY}

Studies in Second Language Acquisition is a refereed journal of international scope devoted to the scientific discussion of acquisition of the use of non-native and heritage languages. Each volume contains four issues, one of which is devoted to a special topic in the field. The other three issues contain research articles of either a quantitative or qualitative nature in addition to essays on current theoretical matters. Other rubrics include shorter articles such as Replication Studies, Squibs, and Research Reports.

\section{PUBLISHING, PRODUCTION, AND ADVERTISING OFFICES}

Cambridge University Press, One Liberty Plaza, New York, NY 10006, USA; US: USAdSales@cambridge. org; or Cambridge University Press, The Edinburgh Building, Shaftesbury Road, Cambridge CB2 8RU, England; UK: ad_sales@cambridge.org

\section{SUBSCRIPTION OFFICES}

(For U.S.A. and Canada) Cambridge University Press, One Liberty Plaza New York, NY 10006, U.S.A. (For U.K. and elsewhere) Cambridge University Press, The Edinburgh Building, Shaftesbury Road, Cambridge CB2 8RU, England.

\section{SUBSCRIPTION INFORMATION}

Studies in Second Language Acquisition (ISSN 0272-2631) is published four times a year in March, June, September, and December by Cambridge University Press. Volume 38 subscription rates: Institutions, print and electronic US $\$ 461.00$ in the U.S.A. and Canada, UK£285.00 in the U.K. and elsewhere; Institution, electronic only US $\$ 370.00$ in the U.S.A. and Canada, UK $£ 229.00$ in the U.K. and elsewhere; Institution, print only US $\$ 438.00$ in the U.S.A. and Canada, UK£267.00 in the U.K. and elsewhere; Individuals, print only US \$142.00 in the U.S.A. and Canada, UK $\$ 88.00$ in the U.K. and elsewhere. Prices include postage and insurance.

This journal is part of the Cambridge Journals Online service. Access to online tables of contents and article abstracts is available to all researchers at no cost. Institutional subscribers: Access to full-text articles online is included with the cost of the print subscription. Subscriptions must be activated; see http:// www.journals.cambridge.org for details.

\section{(C) CAMBRIDGE UNIVERSITY PRESS 2016}

All rights reserved. No part of this publication may be reproduced, in any form or by any means, electronic, photocopying, or otherwise, without permission in writing from Cambridge University Press. For further information see http://us.cambridge.org/information/rights/ or http://www.cambridge.org/uk/ information/rights/ Photocopying information for users in the U.S.A.: The Item-Fee Code for this publication (0272-2631/15 \$15.00) indicates that copying for internal or personal use beyond that permitted by Sec. 107 or 108 of the U.S. Copyright Law is authorized for users duly registered with the Copyright Clearance Center (CCC), provided that the appropriate remittance of $\$ 15.00$ per article is paid directly to: CCC, 222 Rosewood Drive, Danvers, MA 01923. Specific written permission must be obtained for all other copying. Contact the ISI Tearsheet Service, 3501 Market Street, Philadelphia, PA 19104, for single copies of separate articles.

Periodicals rate postage paid at New York, NY, and additional mailing offices. Postmaster: Send address changes in the U.S.A., Canada, and Mexico to: Studies in Second Language Acquisition, Cambridge University Press, Journals Fulfillment Department, One Liberty Plaza, New York, NY 10006, U.S.A.

Studies in Second Language Acquisition is indexed in the Social Sciences Citation Index, Social SciSearch, and Current Contents/Social \& Behavioral Sciences. Coverage began with Vol. 26(1), 2004. 


\section{TABLE OF CONTENTS}

\section{ARTICLES}

L1 Influence on the Acquisition Order of English Grammatical Morphemes: A Learner Corpus Study

Akira Murakami and Theodora Alexopoulou

365-401

Found in Translation: The Influence of the L1 on the Reading of Idioms in a L2

Gareth Carrol, Kathy Conklin, and Henrik Gyllstad

403-443

Incidental Acquisition of Grammatical Features During

Reading in $L 1$ and $L 2$

Denisa Bordag, Amit Kirschenbaum, Andreas Opitz,

Maria Rogahn, and Erwin Tschirner

$445-483$

The Dative Alternation in German-English Interlanguage

Katja Jäschke and Ingo Plag

Does Studying Vocabulary in Smaller Sets Increase Learning?

The Effects of Part and Whole Learning on Second Language Vocabulary Acquisition

Tatsuya Nakata and Stuart Webb

$523-552$

Synchronous Computer-Mediated Communication and Interaction: A Meta-Analysis

Nicole Ziegler

$553-586$

\section{RESEARCH REPORT}

Methodological Choices in Rating Speech Samples Mary Grantham O’Brien 